\title{
The Tshivenda-English Thalusamaipfi/Dictionary as a Product of South African Lexicographic Processes
}

\author{
Mbulungeni Madiba, Multilingualism Education Project, Centre for Higher \\ Education Development, University of Cape Town, Cape Town, South Africa \\ (mbulungeni.madiba@uct.ac.za) \\ and \\ Dion Nkomo, Department of Afrikaans and Dutch, University of \\ Stellenbosch, Stellenbosch and Multilingualism Education Project, Centre for \\ Higher Education Development, University of Cape Town, Cape Town, South \\ Africa (deeouf@yahoo.co.uk)
}

\begin{abstract}
The publication of a dictionary is regarded as the result of a lexicographic process. Three subtypes of a lexicographic process have been noted, namely the primary comprehensive, the secondary comprehensive and the dictionary specific lexicographic processes. In South Africa, the three lexicography processes correspond to the respective mandates of the Pan South African Language Board (PanSALB), the National Lexicography Units (NLUs) and the editorial teams involved in the compilation of the specific dictionaries. This hierarchical arrangement of the lexicographic practice is supported by the government within the country's national multilingual policy which was lauded in linguistic and lexicographic circles as a triumph for cultural democracy. It is almost a decade since these planned lexicographic processes have been in place. It seems the right time to consider the products of these South African lexicographic processes which are envied by many foreign lexicographers, especially in Africa. Accordingly, the article evaluates these lexicographic processes with special reference to the Tshivenda-English Thalusamaipfi/Dictionary. Specifically, it addresses the question: To what extent does this dictionary represent lexicographic development in the indigenous South African languages which were marginalised before the establishment of the NLUs? A few insights are drawn from modern lexicographic theories for the general improvement of future lexicographic practice in languages with limited lexicographic tools such as Venda.
\end{abstract}

Keywords: LEXICOGRAPHIC PROCESS, LEXICOGRAPHIC PLANNING, PANSALB, NATIONAL LEXICOGRAPHY UNITS, LEXICOGRAPHIC PRACTICE, METALEXICOGRAPHY, DICTIONARY, BILINGUAL DICTIONARY, MACROSTRUCTURE, MICROSTRUCTURE

Opsomming: Die Tshivenda-English Thalusamaipfi / Dictionary as 'n produk van Suid-Afrikaanse leksikografiese prosesse. Die publikasie van ' $n$ woordeboek word beskou as die resultaat van 'n leksikografiese proses. Drie ondersoorte van 'n leksikografiese proses is onderskei, naamlik die primêr omvattende, die sekondêr omvattende en die 
woordeboek-spesifieke leksikografiese prosesse. In Suid-Afrika stem die drie leksikografiese prosesse ooreen met die onderskeie mandate van die Pan-Suid-Afrikaanse Taalraad (PanSAT), die Nasionale Leksikografie-eenhede (NLE's) en die redaksiespanne betrokke by die samestelling van die bepaalde woordeboeke. Hierdie hiërargiese rangskikking van die leksikografiese praktyk word ondersteun deur die regering binne die land se nasionale veeltalige beleid wat in taalkundige en leksikografiese kringe geloof is as ' $n$ triomf vir kulturele demokrasie. Dit is byna ' $n$ dekade sedert hierdie beplande leksikografiese prosesse in plek is. Dit lyk na die regte tyd om die produkte van hierdie Suid-Afrikaanse leksikografiese prosesse te beskou wat deur baie vreemde leksikograwe, veral in Afrika, beny word. Gevolglik beoordeel die artikel hierdie leksikografiese prosesse met spesiale verwysing na die Tshivenda-English Thalusamaipfi/Dictionary. Dit roer veral die vraag aan: Tot watter mate verteenwoordig hierdie woordeboek leksikografiese ontwikkeling in die inheemse Suid-Afrikaanse tale wat gemarginaliseer is voor die totstandkoming van die NLE's? 'n Aantal insigte word verkry van moderne leksikografiese teorieë vir die algemene verbetering van die toekomstige leksikografiese praktyk in tale met beperkte leksikografiese gereedskap, soos Venda.

Sleutelwoorde: LEKSIKOGRAFIESE PROSES, LEKSIKOGRAFIESE BEPLANNING, PANSAT, NASIONALE LEKSIKOGRAFIE-EENHEDE, LEKSIKOGRAFIESE PRAKTYK, METALEKSIKOGRAFIE, WOORDEBOEK, TWEETALIGE WOORDEBOEK, MAKROSTRUKTUUR, MIKROSTRUKTUUR

\section{Introduction}

Gouws and Prinsloo (2005: 9) write:

The publication of any dictionary should not only be the result of the preceding compilation activities but it has to be regarded as the culmination of a much more comprehensive set of activities, the so-called lexicographic process. The compilation and eventual publication of any dictionary form part of at least one lexicographic process.

A lexicographic process is "part of a comprehensive historical process which coincides with the development of a language" (Gouws 2001: 65). It is constituted by all the activities leading to the publication of a dictionary as a text (Gouws and Prinsloo 2005: 9). Within the general theory of lexicography (Wiegand 1984: 15), the concept of a lexicographic process may be located within the second constituent theory, namely the theory of organisation. This pertains to lexicographic planning. Planning has been regarded as an important but quite often neglected element of lexicographic practice (Alberts 1999; Gouws 2001, 2003; and Gouws and Prinsloo 2005).

In South Africa, lexicographic planning occurs at both macro and micro level. At macro level, lexicographic planning is done by government through the Pan South African Language Board (PanSALB). Lexicographic planning at micro level is done by the National Lexicography Units (NLUs), the Editors-inchief and their respective editorial teams. At this micro level, planning provides the lexicographer with an opportunity to preview the lexicographic prac- 
tice and prepare for the tasks ahead and their characteristic challenges. It also contributes to the user-friendliness of dictionaries. Dictionaries produced within a well-conceived lexicographic process are characterised by predictability, calculability, analysability and controllability (Gouws 2001: 64). This means that the concept of a lexicographic process provides guidance to the lexicographer, the dictionary user and the dictionary critic in an equally useful way. It is such an essential element of lexicography that when a dictionary fails to be the effective tool that it ought to be, it is quite often regarded as the result of an illconceived lexicographic process, or an absolute absence of planning (Gouws and Prinsloo 2005: 9).

Metalexicography has identified the primary, the secondary and the dictionary-specific lexicographic processes as the three subtypes of a lexicographic process (Gouws 2001, 2003; and Gouws and Prinsloo 2005). Since these have been comprehensively discussed in the cited works, this article mainly focuses on the Tshivenda-English Thalusamaipfi/Dictionary (henceforth TETD) as a product of such processes in South Africa. However, it is not only inevitable but also necessary for background information to discuss the agents of lexicographic processes in the country. These agents are PanSALB, the NLUs, lexicographers and dictionary publishers. Information on the agents of lexicographic processes in South Africa is already available in other published works (cf. Gouws 1996, 2001, 2003; Gouws and Prinsloo 2005; Kumalo 1999; Madiba 2002; and Mongwe 2006). However, in the available literature, this has been done retrospectively to or immediately after the establishment of the NLUs when the authors were generally in an optimistic mood. The exceptions were notably Madiba (2002) who raises critical questions regarding the government's involvement in lexicography and Gouws (2003) who considers a number of potentially negative factors. Overall, what remains missing is an introspective and qualitative evaluation of the operations and products of the South African lexicographic processes close to a decade since their inception. Therefore, the analysis of the TETD in this article, as well as reference to pre-NLUs and other dictionaries, gives another angle to the entire picture.

\section{Agents of lexicographic processes in South Africa}

South Africa is among the very few countries in the world where lexicography has been officially recognised as a professional enterprise with a potential to advance national goals. This occurred in the aftermath of apartheid and the formulation of a multilingual national language policy which recognised nine indigenous African languages as official languages, in addition to English and Afrikaans. Lexicography was rightfully identified as one important way of developing the formerly marginalised languages towards the implementation of the national language policy (Gouws 2003, Madiba 2002). Through PanSALB, which was given a mandate for establishing NLUs for each official language, the South African government facilitated the establishment of the coun- 
try's lexicographic processes. PanSALB was established as an independent statutory body by an Act of Parliament (Act 59 of 1995) with the following explicit aims:

(1) to promote respect for and ensure the implementation of the following principles:

(a) the creation of conditions for the development and for the promotion of the equal use and enjoyment of all the official South African languages;

(b) the extension of those rights relating to language and the status of languages which before 27 April 1994 were restricted to certain regions;

(c) the prevention of the use of any language for the purposes of exploitation, domination or division;

(d) the promotion of

(i) multilingualism; and

(ii) the provision of translation and interpreting facilities;

(e) the fostering of respect for languages spoken in the Republic other than the official languages, and the encouragement of their use in appropriate circumstances; and

(f) the non-diminution of rights relating to language and the status of languages existing before 27 April 1994;

(2) to further the development of the official South African languages;

(3) to promote respect for and the development of other languages used by communities in South Africa, and languages used for religious purposes;

(4) to promote knowledge of and respect for the provisions and principles of the Constitution relating directly or indirectly to language matters;

(5) to promote respect for multilingualism in general; and

(6) to promote the utilisation of South Africa's language resources.

PanSALB had to facilitate all this through the creation of provincial and national structures which would advise on the respective official languages and activities that had to be undertaken. The subcommittee for Lexicography and Terminology played an important role in stressing that dictionaries would figure imperatively in the standardisation process (Gouws 2003: 220). Subsequently, the deliberations regarding the formation of the NLUs for each official language ensued. The NLUs were eventually established according to the PanSALB Act as amended in 1999 (Kumalo 1999, Gouws 2003). This made PanSALB an agent of the primary comprehensive lexicographic process in South Africa. PanSALB's mandate for establishing the NLUs implied several responsibilities which would have direct implications for the production of dictionaries. Since PanSALB identified "the compilation of a comprehensive monolingual explanatory dictionary" as the eventual line function of each NLU (Gouws 2003: 220), it was also its task to assist the NLUs with comprehensive planning to facilitate the achievement of that function. Lexicographically 
speaking, the role of PanSALB was aptly summarised by Gouws (2003: 221) when he wrote:

The task that awaits PanSALB is to define and describe the lexicographic process to be used in South Africa.

PanSALB should realize the compelling need to devise a comprehensive plan for the South African lexicographic process.

The task of defining the primary comprehensive lexicographic process as articulated in the above quotations transcends the administrative and managerial responsibilities of the NLUs. However, Kumalo (1999: 211) wrote at the time: "PanSALB shall not impose itself on the units, but shall make it possible for them to take responsible decisions relevant to their specific and individual needs." It would appear that the formulation of the NLUs, particularly the subsuming of the objectives of the National Lexicography Units Bill and the establishment of the NLUs under PanSALB raised fears of conflicts of interests and control. While these issues are relevant constituents of the theory of organisation, which is part of the general theory of lexicography (Wiegand 1984: 15), they seem to have attracted more attention at the expense of the primary goals for the establishment of the NLUs, i.e. empowering the multilingual nation with relevant, functional and user-friendly dictionaries.

As a law, the PanSALB Act clearly outlined the objectives of each NLU:

The objectives of a unit shall be to initiate, maintain, continue, complete and from time to time improve the compilation of the dictionary and other products by:

(a) the continuous and comprehensive collecting, arranging and sorting, in a lexicographically workable form, of the general vocabulary of the language concerned;

(b) the editing, adaptation, and publication of the collected material according to lexicographic principles in printed and electronic form; and

(c) the granting access to the language material and sources of the unit to researchers according to the policy of the board.

The NLUs were to operate as Section 21 Companies, with each of them managed by a National Lexicography Unit Board. The Constitution of the board was also clearly defined, making provision for:

(a) a Chairperson appointed by the Minister;

(b) an Editor-in-chief [...];

(c) a person appointed by the Minister who, at the request of the Minister, has been nominated by a language body for the language concerned referred to in [...] the Pan South African Language Board Act, 1995 (Act No. 59 of 1995), to represent such body on the board; 
(d) two persons appointed by the Minister, in collaboration with the African Association for Lexicography (AFRILEX), on account of their interest in and knowledge of lexicography;

(e) two persons appointed by the Minister in consultation with stakeholders on account of their knowledge of the language concerned as linguists or mother tongue speakers; and

(f) a person appointed by the Minister on account of his or her marketing skills.

The functions and duties of the boards were listed in Chapter 2 of the Act, Section (6). According to Subsection (1), a board shall in addition to its other functions in terms of this Act:

(a) formulate the policy to be followed to achieve the objectives of its unit;

(b) govern and advise its unit in accordance with the resources at its disposal;

(c) decide from time to time about matters relating to the publishing, printing and reprinting of the dictionary and products of its unit, including the determination of the selling price and conditions of sale of products and services of the unit; and

(d) determine from time to time the number of review, gift, working and other copies of products of its unit to be made available free of charge.

From the foregoing, it is clear that through PanSALB, the government of South Africa has attempted to play not merely a supportive but actually a directive role as an agent of the country's primary comprehensive lexicographic process. Yet it would appear that the process has not been comprehensive enough because no further and adequate elaboration on the production of the relevant lexicographic products has been offered. Perhaps the closest is the document Regulations for the NLUs, which is equally found short of "solutions regarding problems of dictionary planning and compilation" (Gouws 2003: 227). All that could be established was that the NLUs and their boards became agents of the secondary lexicographic processes and through their editorial staff, agents of dictionary-specific lexicographic processes. In all this, metalexicographically relevant pieces of information are missing which would be needed for a model within which the established NLUs could operate. It has to be recalled that prior to the establishment of the NLUs, some languages such as Ndebele had no lexicographic history, experience or expertise to draw from. As part of the primary comprehensive lexicographic process, prospective lexicographers had to be trained from among the linguists of the respective languages. Gouws (2003: 228) indicates that AFRILEX played an important role in this regard, but Sue Atkins, after having offered training together with Michael Rundell at SALEX 98, raises questions in a report (which Gouws substantially quotes) of whether such efforts sufficiently equipped the NLUs for general and languagespecific lexicographic challenges. 
The South African lexicographic processes also needed to win the confidence of the publishing industry. As indicated by Gouws (2001), the agents of the comprehensive secondary lexicographic process and the dictionary-specific lexicographic process should liaise with publishers regarding the publication of dictionaries. This was recognised from the outset when the Nasionale Boekhandel Group, the Oxford University Press (OUP) and the Southern Book Publishers were invited to the third National Language Services workshop which sought to demonstrate the viability of the South African lexicography industry as Beukes (1996) says:

If properly planned and positioned, the lexicography industry in South Africa could - as is the case elsewhere in the world - generate handsome financial benefits which could in turn play a significant role in the process of elaborating the African languages.

Representing OUP, McCallum (1996: 123) dismissed the aim of the seminar as "a somewhat narrow if not misleading view of lexicography" and argued that while there was a genuine need for lexicographic practice in the African languages, certain dictionary types would be non-viable. It is perhaps in this respect that traditional and new dictionary publishers now exist as competitors rather than collaborators with the NLUs. As far as languages are concerned, English and Afrikaans have continued to benefit, with a few commercially viable dictionaries in the African languages being compiled by freelance lexicographers. While this may seem regrettable, in the end it does not matter who produces or publishes what, as long as users are provided with products that may be efficiently used to solve the problems they face in their specific situations of use.

\section{The Tshivenda-English Thalusamaipfi / Dictionary}

The Tshivenda National Lexicography Unit (TNLU) is one of the six NLUs that were established in post-apartheid South Africa (Mongwe 2006: 11), while others were simply reconstituted and named accordingly. Just like the other NLUs with regard to the languages they work on, the function of the TNLU is the compilation of Venda dictionaries. So far, the TNLU has produced only one dictionary, namely the TETD. The TETD was published in 2006, five years after the registration of the TNLU as a non-profit Section 21 Company in 2001 (Mongwe 2006). Although the writing of this dictionary was supported by PanSALB, the TNLU should take all credit and responsibility for its quality. Otherwise it would be very unfortunate if critical decisions regarding the contents and design features were imposed on lexicographers by the stakeholders whose role should be more managerial and logistic than practically lexicographic. In this regard, albeit along the line function that was determined by PanSALB for all the NLUs, the TNLU should have taken into account the fol- 
lowing in their formulation of the dictionary concept and compilation of the TETD:

- the available dictionary types in the language,

- the unavailable dictionary types in the language,

- the potential target users of various types of prospective dictionaries in the language,

- the lexicographic needs of the potential users of the prospective dictionaries,

- the prioritisation, but not total neglect, of certain users and needs over others, and

- the reference skills of the users of the prospective dictionaries.

It is within this set of rubrics that the TETD is evaluated in the following subsections. Attention is given to its typology, its data categories and its structure in view of the identified target users and their needs.

\subsection{A typological perspective on the TETD}

The TETD is presumably a bidirectional bilingual dictionary with two macrostructural lists. The first list coordinates Venda lemmata with their English equivalents while the second list coordinates English lemmata with Venda equivalents. In this perspective, it appears better than Van Warmelo (1937) and Van Warmelo (1989), whose unidirectionality makes them more useful only to Venda speakers trying to learn English. It is outlined on the blurb that the TETD "has been compiled to meet the needs of Tshivenda Home Language learners, First Additional Language learners, Tshivenda students as well as speakers of other languages". The two macrostructures, which are arranged alphabetically, make the dictionary bi-/poly-accessible so that users have options of starting their search path using either Venda or English macrostructural entries. Prior to the TETD, one Venda dictionary having this advantage is Wentzel and Muloiwa's (1976) Trilingual Elementary Dictionary which has three macrostructures. In this way, the TETD clearly embodies the multilingualism agenda of South African lexicography and the post-apartheid national language policy. The availability of blurb texts in both Venda and English is consistent with this idea.

The identification of Venda home language learners, first additional language learners, Venda students as well as speakers of other languages as target users suggests that the TETD was conceived as a learner's dictionary. This observation is problematic, especially when the data categories provided in the dictionary are considered (see 3.2). The limited lexicographic treatment of lemmata can barely support language learning and other functions such as 
translation. In a similar way, the blurb also describes the TETD as an explanatory dictionary. What exactly this means is difficult to understand. According to Hartmann and James (1998: 55), an explanatory dictionary "gives detailed explanations of the meanings covered". As it will be shown in the next section, this dictionary provides very limited treatment of lemmata in either macrostructures which are themselves equally limited. In the comment on the meaning slot, only equivalents and occasional brief paraphrases are provided so that they barely provide the dictionary user with adequate explanatory assistance regarding the lemmata. More details on this will be provided in the next section, on the basis of which it will be determined whether the dictionary may fulfil the functions which it purports to serve, and ultimately whether it marks a major contribution to the development of Venda lexicography in which a small number of dictionaries were already available.

Another aspect which is often used as a typological feature of dictionaries is size, resulting in typological distinctions such as pocket or pocket-size dictionaries, medium-size dictionaries, desk and multi-volume dictionaries. In modern lexicography, size probably remains an important feature only in as far as it is a function of the cost of dictionary production, cost price of the dictionary and convenience of being used in certain situations. Besides these considerations, dictionary size would be superseded by the functional value of the dictionary, which is determined by the availability and accessibility of data categories from which relevant information may be retrieved. However, it may be possible to correlate the size of a dictionary with its functional value within the parameters of a specific type of a dictionary. The two macrostructures of TETD together with a non-integrated (Gouws 2002, 2004) middle-matter add up to only 172 numbered pages. Slightly more than half of this dictionary space is allocated to the Tshivenda-English macrostructure while the remainder is taken up by the English-Tshivenda macrostructure. Even where the smaller is favoured for portability purposes, the functional value of the TETD may easily be put in doubt when compared to some of its predecessors with the same functions. Does the TETD provide more comprehensive assistance compared to Van Warmelo (1989) within its size constraints? A more thorough analysis of the TETD would confirm that it bears little, if any, significant improvements in comparison with some of the available dictionaries in Venda.

\subsection{Data and information categories}

An evaluation of data categories and information which may be retrieved from them is the best way of appreciating the functional value of a dictionary. Within the theory of lexicographic functions, attention is given to the relations existing between specific groups of users, the problems they encounter in certain situations, their information needs for solving the respective problems, and the kinds of information that may be retrieved from the data types available in a dictionary (Bergenholz and Tarp 1995, 2003; and Tarp 2008). It is, therefore, 
not enough for the lexicographer or the dictionary publisher for that matter, to end with identifying the target users and functions of his/her dictionary in the introductory or cover entries. Relevant data categories have to be included in the dictionary so that the information which satisfies certain user needs may be retrieved. When data categories are included without this consideration, the dictionary is likely to become an object which represent less judicious copying from its predecessors, together with their failures (Landau 2001: 23). In cases where the dictionary is the first in the language, as is the case with the IsiNdebele NLU, the dictionary becomes an easily forgettable, if at all recognisable object in a linguistic community. Unfortunately, the potential users of the dictionary normally takes all blame for their lack of dictionary culture, yet such a dictionary culture may only be cultivated by the availability of dictionaries which solve the users' problems with reasonable ease. In this case, the TETD had its forerunners. The evaluation of its data types will inevitably result in its comparison with other Venda dictionaries. The focus will be on lemmata, grammar (type of speech labels) and equivalents, the only consistently provided data types in this dictionary.

\subsubsection{Lemmata}

Although every dictionary contains lemmata, this type of data should not be taken for granted. The lemmatised forms provide spelling information which is useful for literary text production and text reception. For the dictionary to provide optimal support with regard to these functions, important questions will concern the representativeness of the lemma entries. Firstly, was a corpus used as a dictionary basis for lemma selection? Modern lexicography is either corpus-based or corpus-aided, proper use of corpora usually resulting in representative dictionaries which reflect language as it is used. Secondly, if a corpus was used, was the frequency criterion or the predictability criterion adopted for lemma selection? The frequency criterion ensures that dictionaries capture the most frequent words, but for some users, e.g. adult native speakers, the most frequent words may not be the most sought. The use of the predictability criterion, especially in African languages, will save dictionary space by avoiding predictable inflections and derivations. However, the ability to predict will depend on whether the user is a native speaker with a good command of grammar or a second language learner with a limited grammatical competence. Thirdly, was lemma selection guided by policies which ensure that the lexical structure of a language is captured by avoiding biases towards certain word classes (such as nouns) at the expense of other categories? Ultimately, is the lemma stock included in the dictionary appropriate for the users of the dictionary and its functions? In short, lemma selection needs to be carried out in a very meticulous way so that the target users will find the words they look up as punctually as possible.

With an average of 60 lemmata per page, spread over 89 pages of the Tshi- 
venda-English macrostructure, and considering the several less than halfprinted pages at the end of certain alphabetical stretches, the TETD's Tshivenda vocabulary coverage is \pm 5000 items. This may be suitable for additional language learners, Venda students and speakers of other languages learning Venda, provided it satisfies the other questions of balance raised in the previous paragraph. It is commendable that the lemmata represent different word categories as well, although there seems to be a prevalence of nouns and verbs, which is characteristic of the earliest dictionaries of which the lemma selection was based on traditional methods. Another problem is that no information is provided on whether a corpus formed the basis for the dictionary or not. For example, if the frequency criterion, based on a corpus was used, indicating frequency would guide non-native Venda learners on the vocabulary they need to learn for basic communication purposes. This is done in the Oxford Bilingual School Dictionary: Northern Sotho and English (De Schryver 2008). Furthermore, a comparison of the English wordlists in the TETD and other bilingual dictionaries compiled by other NLUs working on languages with more or less similar levels of lexicographic development indicates that the hub and spoke model suggested by Gouws (2003) for bilingual dictionaries was not employed. For example, only 23 lemmata are common to both the first 60 lemma stretches of the TETD and Dikixinari ya Xitsonga/English Dictionary. Thus, as the editors also do not provide it, it is difficult to determine the dictionary basis of the TETD. The provision of such information would indicate the appropriateness of the dictionary for the four different types of identified target users. However, there seems to be a striking pattern when the Tshivenda-English section is compared with Murphy's (1997) online Venda dictionary. When the letter Aa alone is compared with the online dictionary, it is found that, with the exception of function words and loan words, all the lemmata in Murphy's dictionary are entered and treated similarly in the TETD. It would not be wrong for the TETD to have Murphy's and other existing dictionaries as its dictionary basis. However, what is remarkable is the minimum effort that went into making the TETD better than its predecessors, in line with the needs of the users the editors identified.

Given that the TETD was compiled at a time when several dictionaries existed in Venda, its vocabulary coverage may be far too limited for home language learners, who may be assumed to be the primary users of the dictionary. Of course, the TETD would have an advantage of containing contemporary vocabulary, but this would suggest that certain words in the older dictionaries would be excluded. Yet some such lemmata may be of cultural relevance to most target users. This brings back the issue of dictionary size, and the fact that the dictionary should have clearly prioritised certain users, either home language learners or additional language learners, because it cannot equally satisfy the needs of these totally different users. A dictionary for all is a dictionary for none or, worse still, no dictionary at all, if the functional value of the dictionary does not take precedence. 


\subsubsection{Grammar}

The main basis for the rejection of the suggestion that the TETD may be regarded as a learner's dictionary is that, in addition to its limited macrostructure which makes it difficult for the dictionary to support vocabulary learning, very limited grammatical information is provided as part of the microstructural treatment. Only type of speech information is given. The table below presents the most used type of speech labels in the dictionary.

\begin{tabular}{|l|l|l|l|}
\hline $\begin{array}{l}\text { Word class } \\
\text { (English) }\end{array}$ & $\begin{array}{l}\text { English } \\
\text { Abbreviation }\end{array}$ & $\begin{array}{l}\text { Word class } \\
\text { (Venda) }\end{array}$ & $\begin{array}{l}\text { Venda } \\
\text { Abbreviation }\end{array}$ \\
\hline Noun & N & dzina & dzin \\
\hline Verb & V & liiti & lii \\
\hline Adjective & Adj & litaluli & litalu \\
\hline Preposition & Prep & livhofhi & livho \\
\hline Adverb & Adv & lidadzisi & lida \\
\hline Conjunction & Conj & litanganyi & litang \\
\hline Possessive & Poss & lisumbavhune & livhun \\
\hline
\end{tabular}

Type of speech information in the TETD

Type of speech labels represent important grammatical data provided in dictionaries. In the TETD, type of speech labels serve to distinguish between homographs, as is the case with the two lemmata represented by the form anga. After the first lemma anga, lii informs the user that the lexical item is a verb, while livhu indicates that the lexical item treated in the second lemma anga is a possessive. Unfortunately, some of the grammatical markers used in the dictionary articles are inconsistent with those supplied for guidance in the front matter. For example, livhu is used to indicate that anga may be used as a possessive equivalent to the English words mine or my, yet livhun is given in the front matter as the abbreviation indicating possessives. Furthermore, grammatical markers are the only type of grammatical information the user finds in the dictionary. How the treated words combine with others in speech or writing is not provided, especially for the help of additional language learners. Example sentences, possibly derived from real texts, would have been useful. It would have been better if a grammatical section was provided to furnish nonnative speakers with grammatical rules and guidance which may help them when learning to speak or write Venda. Moreover, a combined explanation giving the full form of a Venda symbol or abbreviation, together with its English equivalents with which non-native Venda learners may be familiar, as attempted in the table above, would have been useful. Otherwise the user is left struggling with the coordination of the symbols and abbreviations and their full forms in the two languages. This is not only cumbersome but also discouraging for the user. 


\subsubsection{Equivalents}

In both sections of the TETD, equivalents are the main data categories provided in the comment on meaning slot. Al-Kasimi (1977: 60) distinguishes two types of equivalents that are normally supplied by bilingual dictionaries, namely translational equivalents and explanatory equivalents. A translational equivalent is "a lexical unit which can be immediately inserted into a sentence in the target language". An explanatory equivalent is one "which cannot always be inserted into a sentence in the target language" and it tends to approximate a translational unit. Owing to linguistic and cultural anisomorphism between English and African languages such as Venda, both translational and explanatory equivalents are provided in the TETD, the former for lexical items which signify universal phenomena and the latter in the case of culture-specific or context-dependent words.

In addition to translational and explanatory equivalents, the TETD also treats the meaning of some lemmata by providing explanations in the target language. These explanations are brief paraphrases or descriptions which seem to be used in cases where there are no translational equivalents. They are used either to clarify the explanatory equivalent or on their own in the comment on meaning. A close look at the TETD shows that, although explanations are used in both sections of the dictionary, they are more prevalent in the TshivendaEnglish section. The following are illustrations of the use of explanations as data from which meaning can be retrieved in the dictionary:

aini ... iron, an instrument used to make clothes smooth

dzengaila ... restless, always on the go

founela ... phone, make a phone call

davha ... work party held by one who wants to have the land ploughed or cultivated

mbongo ... food prepared from freshly harvested maize

shula ... smear the floor with cow dung

In these examples, the TETD diverts from the dominant procedure of providing meaning by exclusively using equivalents. Instead, brief explanations which may be regarded as definitions are supplied. In the first three examples, iron, restless and phone are provided as equivalents for aini, dzengaila and davha respectively. However, the equivalents are supplemented by brief explanations providing the meaning in more detail and accuracy. In the case of the first and third examples, the explanations serve as meaning discriminators, because iron and phone have other meanings as well, with the former also referring to metal in general, while the latter may also be used as a noun.

With the fourth and fifth examples, the use of explanations to provide meaning is quite different from the first three examples. In the latter, the explanations are the sole data categories providing meaning. In such cases, the explanations are provided because neither translational nor explanatory equiv- 
alents exist for the particular lexical items. The Venda lemmata refer to culturespecific phenomena which are probably not known in English and therefore have no English equivalents. Thus the adoption of brief explanations becomes the best strategy for presenting meaning. Although the provided paraphrases of meaning may not be easily inserted as translational equivalents for the lemmata, the explanations are given in informative sentences, leaving the user with an unequivocal idea of the meaning of lemmata. The problem, as stated earlier, is that they are used sparingly and without a clear and consistent policy. The TETD users, especially non-native learners of Venda, would actually wish that these explanations were provided in cases where lemmata are polysemous or where at least two partly synonymous equivalents are provided for lemmata. They would be an effective meaning discrimination strategy in such problematics as described in the next paragraph.

Meaning discrimination is probably one of the most difficult tasks nonnative Venda learners have to contend with while using the TETD. The importance of meaning discrimination in bilingual dictionaries has been supported by scholars such as Al-Kasimi (1977), Mafela (2005) and Yong and Peng (2007). Al-Kasimi (1977: 67) notes that the need of meaning discrimination in bilingual dictionaries arises when the user is "confronted with several words which he cannot distinguish one from another". This is usually obtains owing to polysemy and synonymy. Therefore, as Yong and Peng (2007: 143) state, meaning discrimination "helps to answer the question of which sense is to be taken in the specific target language situation and guide the dictionary user towards the right or appropriate target language equivalent". Because of the absence of such help, Mafela (2005) criticises the earlier Venda dictionaries preceding the TETD. Unfortunately, the TETD, which was published a year later, is also lacking in this respect. The following examples illustrate how the TETD would have been more user-friendly had effective meaning discrimination strategies been employed.

pfa ... hear, feel, taste, understand; spit

vhafuwi ... farmers; Chief

tama ... wish, admire, desire, be eager, envy, prefer, crave

Confronted with the above articles from the TETD, a non-native Venda learner will find it difficult to choose the correct equivalent. In the first example, the lemmata pfa and vhafuwi are polysemous and their English equivalents can scarcely be used as synonyms. In the third example, the equivalents of the lemma tama may be regarded as synonyms. However, they cannot be used interchangeably in all contexts. All this indicate that the problems pointed out by Mafela (2005) regarding Venda dictionaries still prevail in the TETD. This suggests that in the compilation of the dictionary, adequate regard has not been given to metalexicography and therefore the limitations identified in the preceding Venda dictionaries have been repeated. 


\subsection{The TETD as a reflection of the South African lexicographic process}

The TETD is a product of the lexicographic process through which a government-supported initiative of developing the country's official languages saw the establishment of NLUs for each language. For African languages such as Ndebele and Tsonga, such an initiative would see the production of the very first dictionaries. Yet in other languages such as Afrikaans, English, Xhosa and Zulu, lexicographic work has been going on for quite a long time. The establishment of formal structures for lexicographic purposes has improved the execution of lexicographic works in these languages.

While no structures existed for Venda lexicography before the establishment of the TNLU, there were at least a few lexicographic products on which to rely. Details about the forerunners of the TETD are outlined in Mawela (1999), Mongwe (2006) and Mafela (2008). These include Marole (1932, 1955, 1955a), Marole and De Gama $(1936,1954)$ and Van Warmelo $(1937,1958,1989)$. Very little literature on these dictionaries is available. For example, none of these dictionaries has any recognisable keyness in De Schryver (2009), in which no names of Venda lexicographers are mentioned while 'Venda' and 'Tshivenda' carry low keyness values. According to De Schryver (2009: 389), Venda (Tshivenda) together with Tsonga (Xitsonga), compared to the other official South African languages, is not often discussed in lexicographic settings. It is only in Lexikos 9, 15 and 18 where Venda lexicographic works are discussed. Of the three articles, only Mafela (2005) discusses Venda lexicography in such a way that the quality of future dictionaries could be improved. Unfortunately, it appears to have been too late for Mafela (2005) to contribute to the quality of the TETD. The analysis of the TETD indicates that it does not reflect recent theoretical and methodological advances in lexicography. It cannot be convincingly explained who the real users of the dictionary are and how they are likely to benefit from consulting it, as it barely shows significant improvements on the dictionaries already existing before its compilation. What is significant though, is that this may not be regarded as the failure of the TNLU per se. The dictionary may rightfully be seen as a reflection of a lexicographic achievement of the comprehensive lexicographic process initiated through the establishment of the NLUs following the demise of apartheid. It is remarkable that without the words Tshivenda/Venda on its cover and front matter pages, the TETD is more or less similar to the IsiNdebele/English Isihlathululi-magama Dictionary, Sesotho sa Leboa/English Pukuntsu Dictionary and Dikixinari ya Xitsonga/English Dictionary if the names of the languages treated in these dictionaries are omitted. Not only their cover entries but also their front matter texts are identical, providing very little information about the language, the procedures followed at various stages of dictionary compilation, and, despite being called explanatory dictionaries, limited macrostructural representation and lexicographic treatment of lemmata. This is disappointing because, before the establishment of the NLUs, different needs were identified by the different language repre- 
sentatives at the 1996 lexicography meeting, which logically means that the NLUs had to produce different dictionaries to satisfy the different needs experienced in the respective languages.

The above situation has possibly changed the general perception about government-planned lexicography, which was initially celebrated (Madiba 2002). This has seen the emergence of a parallel lexicographic process initiated by publishers and undertaken by free-lance lexicographers. The obvious case in point is represented by the Oxford bilingual dictionaries, namely the Oxford Bilingual School Dictionary: Northern Sotho and English and the Oxford Bilingual School Dictionary: Zulu and English, both edited by Gilles-Maurice de Schryver. These Oxford dictionaries promise to be a great success not only because of their more prestigious publisher, but also because of an unambiguous identification of their target users and efforts of meeting the needs of these target users, who are primarily school learners of either of the treated languages. Not only have the dictionaries been recognised by the Department of Education as useful language learning instruments, but the Northern Sotho and English dictionary has also won the SATI (South African Translators' Institute) award for outstanding translation dictionaries in 2009. This shows that the dictionaries have not focused on specific users and functions at the neglect of others. These dictionaries may also serve as useful translation instruments. However, it should be reiterated that while these dictionaries are generally different from and of better quality than those produced by the NLUs, the recognition of the potential of lexicography in South Africa has created a favourable climate for lexicographic practice, either by the NLUs or by commercial lexicographers. In short, the South African lexicographic processes have seen an upsurge of lexicographic practice, with dictionaries of varying quality being produced, through governmental and commercial structures.

\section{Conclusion}

This article has attempted to add an important and over-due dimension to the metalexicographic account of the South African lexicographic processes. This dimension is the evaluation of the outputs of lexicographic practice since the establishment of the NLUs about a decade ago. The establishment of the NLUs remains a commendable idea which has undoubtedly improved lexicographic practice in the country. Lexicographers who previously faced different challenges as they worked on languages with established lexicographic history albeit within constrained frameworks found themselves working with the sanction of a democratic South Africa. On the other hand, formerly marginalised languages, now have lexicographers working with other language practitioners, albeit with more challenges owing to a lack of a favourable lexicographic history in their languages. The net effect is that all of South Africa's official languages have at least one dictionary. While some of the dictionaries are likely to fare unfavourably when subjected to dictionary criticism, they are certainly a 
step forward in the attainment of perfect dictionaries (Gouws and Prinsloo 2005: 42). The South African lexicographic community will gradually become lexicographically informed owing to the dictionaries that have been produced over the last decade and the lexicographers will certainly benefit from their acquired experience. Ultimately, more and better dictionaries will hopefully be produced. However, for this to happen, more insights are needed into the efficiency of and challenges to the country's lexicographic establishment, especially the NLUs, so that its operations may be improved. More theoretical insights are also required to support the lexicographic practice. For example, Atkins (2002: 9) stresses that for devising tomorrow's dictionary it will be necessary to pay attention to, among other considerations, "a clear idea of its users and what they are going to do with it". This article has focused on one dictionary which seems quite problematic concerning this issue. It is evident that there is room for improvement of the available products of the South African lexicographic processes, especially given that the bilingual dictionaries such as the TETD have to be considered as a step towards the production of comprehensive explanatory monolingual dictionaries for the official languages.

\section{References}

Alberts, M. 1999. The Importance of a Business Plan when Planning a Lexicographic Project. Lexikos 9: 188-197.

Al-Kasimi, A.M. 1977. Linguistics and Bilingual Dictionaries. Leyden: E.J. Brill.

Atkins, S. 1998. Some Discussion Points Arising from Afrilex-Salex'98. Unpublished Course Evaluation Document. Pretoria: University of Pretoria.

Atkins, S. 2002. Bilingual Dictionaries: Past, Present and Future. Correard, M.-H. (Ed.). 2002. Lexicography and Natural Language Processing. A Festschrift in Honour of B.T.S Atkins. Stuttgart: EURALEX.

Bergenholtz, H. and S. Tarp (Eds.). 1995. Manual of Specialised Lexicography: The Preparation of Specialised Dictionaries. Amsterdam/Philadelphia: John Benjamins.

Bergenholtz, H. and S. Tarp. 2003. Two Opposing Theories: On H.E. Wiegand's Recent Discovery of Lexicographic Functions. Hermes, Journal of Linguistics 31: 171-196.

Beukes, A.-M. 1996. Preface. Lexicography as a Financial Asset in Multilingual South Africa: 97-110. Pretoria: Department of Arts, Culture, Science and Technology.

De Schryver, G.-M. 2009. Lexikos at Eighteen: An Analysis. Lexikos 19: 372-403.

De Schryver, G.-M. et al. (Eds.). 2008. Oxford Bilingual School Dictionary: Northern Sotho and English / Pukuntšu ya Polopedi ya Sekolo: Sesotho sa Leboa le Seisimane. Cape Town: Oxford.

De Schryver, M.-G. et al. (Eds.). 2010. Oxford Bilingual School Dictionary: Zulu and English / Isichazamazwi Sesikole Esinezilimi Ezimbili: Isizulu NesiNgisi. Cape Town: Oxford.

Golele, N.C.P. 2005. Dikixinari ya Xitsonga / English Dictionary. Cape Town: Pumelela.

Gouws, R.H. 1996. A Sequence for Meeting Lexicographic Needs. Lexicography as a Financial Asset in Multilingual South Africa: 97-110. Pretoria: Department of Arts, Culture, Science and Technology. 
Gouws, R.H. 2001. Lexicographic Training. Approaches and Topics. Emejulu, J.D. (Ed.). 2001. Éléments de lexicographie gabonaise. Tome I: 58-94. New York: Jimacs-Hillman.

Gouws, R.H. 2003. Towards the Formulation of a Theoretically Motivated Model for the National Lexicography Units in South Africa. Hartmann, R.R.K. (Ed.). 2003. Lexicography: Critical Concepts: 218-246. London/New York: Routledge.

Gouws, R.H. 2004. Outer Texts in Bilingual Dictionaries. Lexikos 14: 67-88.

Gouws, R.H. and D.J. Prinsloo. 2005. Principles and Practice of South African Lexicography. Stellenbosch: SUN PReSS.

Hartmann, R.R.K. and G. James. 1998. Dictionary of Lexicography. London/New York: Routledge.

Kumalo, M.B. 1999. The National Lexicography Units - Existing and Prospective. Lexikos 9: 211216.

Landau, S.I. 2001. Dictionaries. The Art and Craft of Lexicography. Second Edition. New York/Cambridge: Cambridge University Press.

Madiba, M. 2002. Lexicography Planning in a Post-Apartheid South Africa: What Government Has to Do with it. Paper presented at 'A Gathering of Dictionaries' seminar, organised by the Dictionary Research Centre at the University of Birmingham, 10 May 2002.

Mafela, M.J. 2005. Meaning Discrimination in Bilingual Venda Dictionaries. Lexikos 15: 276-285.

Mafela, M.J. 2008. L.T. Marole: A Forgotten Pioneer in Tshivenda Lexicography. Lexikos 18: 366373.

Mahlangu, K.S. (Ed.). 2006. IsiNdebele/English Isihlathululi-magama Dictionary. Cape Town: Pumelela.

Marole, L.T. 1932. Phrase Book for English and Venda. Sibasa: Marole Book Depot.

Marole, L.T. 1955. Afrikaans-Venda: Vocabulary and Phrase Book. Sibasa: Marole Book Depot.

Marole, L.T. 1955a. Phindulano: English-Venda Phrase Book. Sibasa: Marole Book Depot.

Marole, L.T. and F.J. de Gama. 1936. English-Tshivenda Vocabulary. Sibasa: Marole Book Depot.

Marole, L.T. and F.J. de Gama. 1954. English-Venda Vocabulary. Third edition. Sibasa: Marole Book Depot.

Mawela, A. 1999. The State of Tshivenda Lexicography. Lexikos 9: 251-254.

McCallum, K. 1996. Oxford University Press. Lexicography as a Financial Asset in Multilingual South Africa: 121-126. Pretoria: Department of Arts, Culture, Science and Technology.

Mojela, V. (Ed). 2006. Sesotho sa Leboa / English Pukuntšu Dictionary. Cape Town: Pumelela.

Mongwe, M.J. 2006. The Role of the South African National Lexicography Units in the Planning and Compilation of Multifunctional Bilingual Dictionaries. Unpublished M.Phil. Thesis. Stellenbosch: Stellenbosch University.

Murphy, M.L. 1997. Venda: CBOLD [online]. http://www.cbold.ddl.ishlyon.cnrs.fr/CBOLD Lexicons/Venda.Murphy1997. [Accessed 11 January 2010.]

Tarp, S. 2008. Lexicography in the Borderland between Knowledge and Non-knowledge. General Lexicographical Theory with Particular Focus on Learner's Lexicography. Lexicographica. Series Maior 134. Tübingen: Max Niemeyer.

Tshikota, S. (Ed.-in-chief). 2006. Tshivenda-English thalusamaipfi ya u talutshedza ya nyambombili/ English-Tshivenda Bilingual and Explanatory Dictionary. Cape Town: Pumelela.

Van Warmelo, N.J. 1937. Tshivenda-English Dictionary. Department of Native Affairs. Ethnological Publications Vol. VI. Pretoria: Government Printer. 
Van Warmelo, N.J. 1958. Teo dza Tshivenda: Venda Terminologie - Venda Terms. Coined for use in schools by the Venda Language Committee. Department of Native Affairs. Ethnological Series No. 39. Pretoria: Government Printer.

Van Warmelo, N.J. 1989. Venda Dictionary: Tshivenda-English. Pretoria: J.L. van Schaik.

Wentzel, P.J. and T.W. Muloiwa. 1976. Drietalige Elementêre Woordeboek/Trilingual Elementary Dictionary: Venda-Afrikaans-English. Documenta No. 16. Pretoria: University of South Africa.

Wentzel, P.J. and T.W. Muloiwa. 1982. Thalusamaipfi ya nyambotharu yo khwiniswaho: LuvendaLuvhuru-Luisimane/Verbeterde drietalige woordeboek: Venda-Afrikaans-Engels/Improved Trilingual Dictionary: Venda-Afrikaans-English. Pretoria: University of South Africa.

Wiegand, H.E. 1984. On the Structure and Contents of a General Theory of Lexicography. Hartmann, R.R.K (Ed.). 1984. LEXeter '83 Proceedings. Papers from the International Conference on Lexicography at Exeter, 9-12 September 1983: 13-30. Lexicographica. Series Maior 1. Tübingen: Max Niemeyer.

Yong, H. and J. Peng. 2007. Bilingual Lexicography from a Communicative Perspective. Terminology and Lexicography Research and Practice 9. Amsterdam/Philadelphia: John Benjamins. 